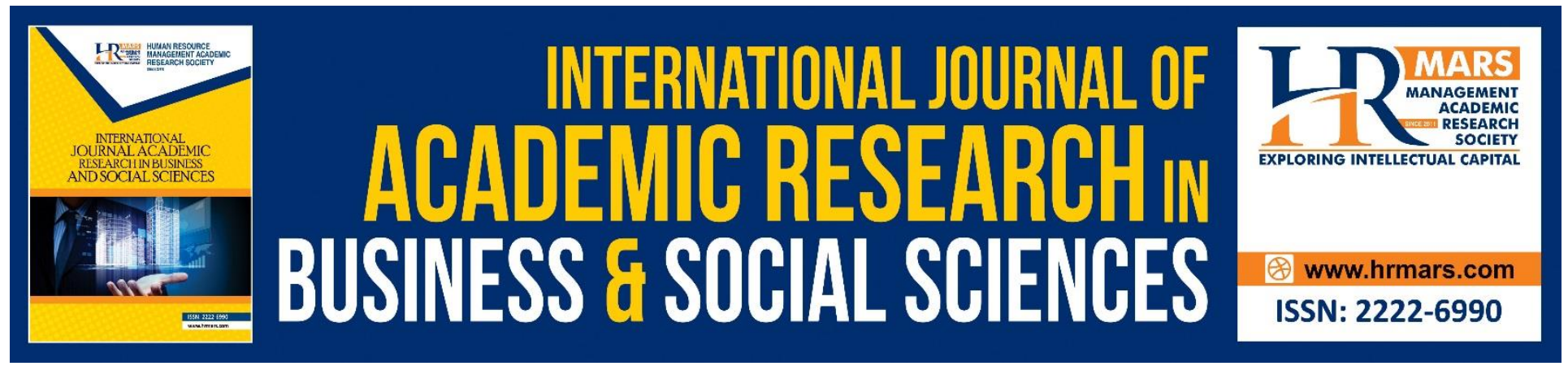

\title{
The Stumbling and Building of Noodle Bowl Effect of Convergence of Trans-Pacific Partnership (TPP) and Regional Comprehensive Economic Partnership (RCEP)
}

A. M Dayang Affizzah, Ting Mei Sing, Nurul Aida A.

To Link this Article: http://dx.doi.org/10.6007/IJARBSS/v11-i14/8562

DOI:10.6007/IJARBSS/v11-i14/8562

Received: 07 November 2020, Revised: 03 December 2020, Accepted: 30 December 2020

Published Online: 26 January 2021

In-Text Citation: (Affizzah et al., 2021)

To Cite this Article: Affizzah, A. M. D., Sing, T. M., \& A., N. A. (2021). The Stumbling and Building of Noodle Bowl Effect of Convergence of Trans-Pacific Partnership (TPP) and Regional Comprehensive Economic Partnership (RCEP). International Journal of Academic Research in Business and Social Sciences, 11(14), 164-181.

Copyright: (C) 2021 The Author(s)

Published by Human Resource Management Academic Research Society (www.hrmars.com)

This article is published under the Creative Commons Attribution (CC BY 4.0) license. Anyone may reproduce, distribute, translate and create derivative works of this article (for both commercial and non-commercial purposes), subject to full attribution to the original publication and authors. The full terms of this license may be seen

at: http://creativecommons.org/licences/by/4.0/legalcode

Special Issue: Contemporary Business and Humanities Landscape Towards Sustainability, 2021, Pg. 164 - 181

Full Terms \& Conditions of access and use can be found at http://hrmars.com/index.php/pages/detail/publication-ethics 


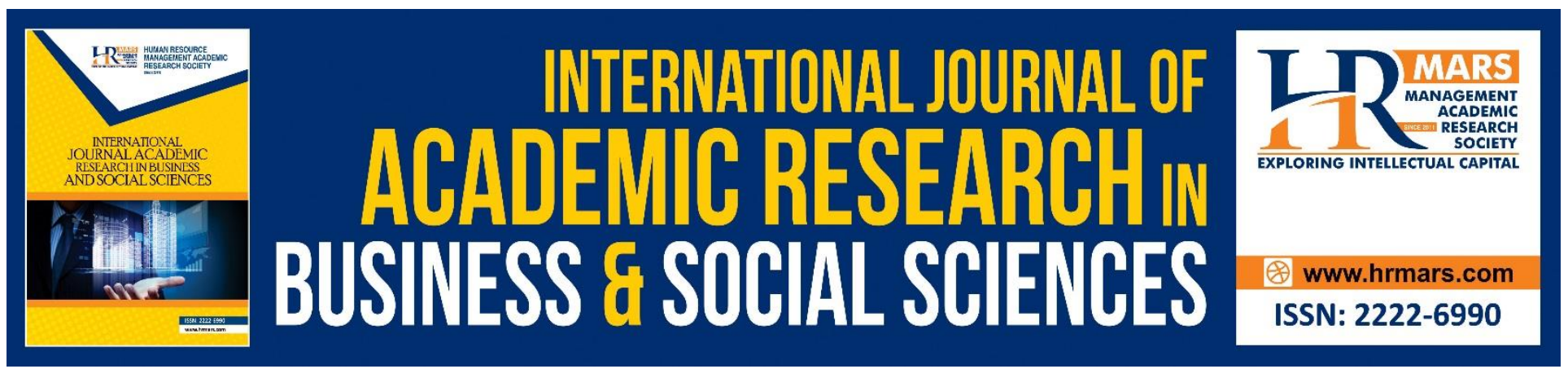

\title{
The Stumbling and Building of Noodle Bowl Effect of Convergence of Trans-Pacific Partnership (TPP) and Regional Comprehensive Economic Partnership (RCEP)
}

\author{
A. M Dayang Affizzah, Ting Mei Sing, Nurul Aida A. \\ Faculty of Economics and Business, Universiti Malaysia Sarawak, Kota Samarahan, Sarawak \\ Email: amdaffizah@unimas.my
}

\begin{abstract}
The study focus on convergence in 12 countries TPP (Trans-Pacific Partnership) and 16 countries RCEP (Regional Comprehensive Economic Partnership) member countries, particularly in respect to total trade for the period 2000-2017. This study uses the non-linear approach model, transition Path, and log t-test by Philip and Sul. The Trans-Pacific Partnership's overall convergence among member countries shows it is diverging, and clustered themselves into four convergence clubs. As for Regional Comprehensive Economic Partnership's overall convergence reflects it is converging though could be interpreted as a weak convergence, and clustered themselves into four convergence clubs. The study concludes that it is keen towards RCEP, as it shows more similarities and unity among participating member as to compare with TPP.
\end{abstract}

Keyword: Convergence, Trans-Pacific Partnership, Regional Economic Partnership, Noodle Bowl Effect

\section{Introduction}

Stated by the TPP Trade Minister Report to Leaders (2014), "TPP is a comprehensive, next generation regional agreement that liberalizes trade and investment and address new and traditional trade issues and 21st century challenges". It's framework is melded to be a comprehensive agreement that (1) demolish trade barriers in goods and services, (2) move even further than the 'WTO-Plus' trade rulebook on subjects not addressed by WTO disciples, (3) explore ways to develop a more effective regulatory policies in covering all sectors which have effect on trade and investment flows. In general, TPP is testing and maximizing their trade potential to be a better choice than the existing WTO as well as other FTAs, hence putting their benchmark for future trade negotiations.

RCEP primary focus is more towards consolidating the smaller scale of FTAs goals and issues. It concerns on resolving the noodle bowl problems among ASEAN +6 FTAs. Besides, establishing a 
comprehensive and mutually benefiting agreement, it also aim to have a deeper engagement and make-better existing ASEAN+1 FTAs towards the pursuit of extension in trade and investment within regions. Though, in such ways RCEP have no intention to tear down other corresponds FTAs, instead it will try to unified and harmonize rules and regulations that contributes to the divergence among countries in the region.

As of 2016, there are 12 countries in the Asia-Pacific region that have joined in TPP. Other countries like, Thailand, Taiwan, Colombia, Costa Rica and Thailand have also taken interest and want to join in. The TPP membership procedure is very tedious, as it involves many bilateral discussions and endorsement from every existing member and a mutual decision. Interestingly, the United States withdrawal from the Trans-Pacific Partnership has brought about its reconfiguration by the other 11 countries that have decided to remain in it, creating another dimension of the former TPP, leading into the Comprehensive and Progressive Agreement for Trans-Pacific Partnership, CPTPP, or TPP-11.

Whilst in RCEP, there are 16 countries, 10 of which are ASEAN members also 12 RCEP members are also APEC members. RCEP memberships are not ready to open for all, because any countries that have yet made any FTA with ASEAN cannot join RCEP, to date. As of now, it is still emphasizing on linkages among East Asia region only. Nevertheless, an important and unique feature offered by RCEP is the flexibility towards less developed countries, hence the special treatment. This approach is aligned with their stand on focusing towards developmental issues above others.

In the recent years, Trans-Pacific Partnership (TPP) and Regional Comprehensive Economic Partnership (RCEP) has been a heated and debatable topic worldwide. Since it's official debut, people have been paying close attention to the agreement's agenda, negotiations, implications etc and with the new controversial issues of United Stated backing out from TPP (as of early 2017) as well as the trade war between two giant economies namely United States and China, many are starting to make speculations and predictions on TPP and RCEP's future. On top of that, it is also very interesting to observe that some countries that are participating in TPP are also in RCEP, hence raising questions of opting for only one or both partnerships? The more intriguing debates are to identify the core group or countries that can 'hold' the partnership together. Therefore, there is always the need to go deeper and wider in investigating these free trade agreements, so that a more comprehensive outlook can be addressed.

The study focus on total trade convergence of TPP and RCEP intends to give a general picture and a better understanding on what are TPP and RCEP. Besides reviewing their individual capabilities and drawbacks, it will also discuss on the possibilities that made these countries converge or diverge among each other as well as the advantages of certain countries participating in any particular agreement. Thus with a greater understanding of what both partnerships 'brought to the table', the country can decide more objectively. Furthermore, this study mainly focuses on finding and clustering all participating countries into their own standards and capabilities in terms of total trade. Hence, with this knowledge the authorities could put more effort in building economic integration that will eventually contribute to the convergence of these countries.

\section{Literature Review}

The study by Ben-David (1996), seeks to find the relationship between international trade and income convergence in groups of countries that have partnerships. The paper agrees that, there is a 
higher possibility of income convergence among richer countries while for some other countries, they display lower or even no convergence at all (Baumol, 1986). Next, instead of the usual cross country regressions Ben-David uses the annual dispersion method to see the relations of convergence process and liberalization process timings. Noted here that, not only that he uses countries that have major trade partners, he also randomly compare it with different country groupings to see the extend of income convergence. Ultimately, results show that a more significant income convergence can be observed within the group that has trade partnerships than the ones that has been randomly grouped.

Through the method of charting and explaining growth and trends of FTAs within the Asia Pacific region, Dent (2010), intends to search for more reliable options in terms of regional and plurilateral agreements. This is because, he claims that, an economically dependable and of high quality FTAs are 'running out' on top of the ones who after years turn inactive. Moreover, the author also acknowledges the convergences and harmonization of the countries he analyzed plus noting that some extended versions of FTAs have better and stronger prospects compared to the original.

Apergis, Christou and Miller (2012), paper's objective, is to find convergence club in respect to the nine development indicators via methods of Phillips and Sul. Generally, results does not backup the hypothesis that at a certain point all countries will converge in a equilibrium state. Beside, estimating the per capita output, they have also compare it with the nine development indicators mentioned. Findings shows, there were seven different convergence clubs in per capita output and also evidently, converging clubs in financial development and per capita output is significant and supportive of each other. Borsi and Metiu (2013); Andronnikova (2014) have applied the non-linear later factor method in order to find the economic convergence in real income per capita among the 27 EU countries between the year 1970 till 2010. To their analysis, there are no full panel convergence in EU, but found convergence clubs that converge into their own real income per capita steady states, plus regional linkages helps in determining the clustering.

As studied by Petri, Plummer and Zhai (2014), they pursued on a study that quantifies the benefit gains received for every country that are involved in TPP, RCEP and also FTAAP. Estimations on benefits were made using the Computable General Equilibrium (CGE) model on top of that, the researchers have also included a new set of estimates to cater for China joining TPP, as of the year 2014. Petri and Abdul-Raheem (2014) did their research on a new FTAAP agreement that is perceived to complement TPP and RCEP if either one fail to enlarge and achieve region wide integration. Hence, their objective is to study all negotiating pathways and estimates their benefits. This has been done through reviewing TPP and RCEP strategy pathways, comparing TPP and RCEP objectives and lastly the application of advanced and Computable General Equilibrium (CGE) model. Findings suggest that, the deepening of economic integration in Asia-Pacific could generate large economic benefits and also help minimizing geopolitical issues.

Basu Das and Jagtiani, explores in depth about RCEP especially on its issues and challenges it brings as well as the potential of expanding towards FTAAP (2014). Through analyzing RCEP's rationale, economic sectors, developments gaps, tariffs elimination, benefits and implications, basically the authors have found that, RCEP have great potential to be a building block for the multilateral trading system.

Battisti, Vaio and Zeira (2016), worked on a new method to calculate divergence of output across countries through measuring how closely output per worker, productivity and technology in 
each country follow the global frontier. In a way, their empirical result could identify countries that follow the frontier fully along with the ones who are left behind. Moreover, some of the empirical literature used in their paper have mixed opinions, for instance, a remark that state all countries in the world are actually converging, but to their own steady and even some studies that are criticized for its biasness that focuses only on overall distribution and not the countries individually. Therefore, with this new method introduced, the study have found that in a period of 1970 till 2008, many countries are not all the way catching up with the frontier, hence we can see a significant divergent. To add on, their result was also in fact the gist idea and consistent from their previous work (Battisti, Vaio \& Zeira, 2015), whereby although there's convergence in a long run productivity path in terms of output per worker in each country, but for many other countries it is still diverging away from global frontier.

Other than that, a study has been done by Affizah et al (2017), on finding the convergence of RCEP countries in respect to income. However, it was observed that, there was too much difference in output inequalities between members and regions, hence the need of finding club convergence. The income data was taken from year 1997 to 2015, and tested with the non-linear approach. Seven clubs were formed, indicating a weak convergence between members. The pivotal clubs comprises of developed countries like Brunei, New Zealand, Japan and Singapore, a club for the newly industrialized economies (NIE's) consisting of Indonesia, Thailand, Malaysia and China and the rest formed a club of countries that converge towards each other. Besides that, the transition path shows a positive signal for countries to catch up with each other's economic growth.

\section{Methodology}

\section{Data Description}

Countries in the study includes; Trans Pacific Partnership (TPP) namely Australia, Brunei, Chile, Malaysia, New Zealand, Peru, Singapore, United States and Vietnam also countries in the Regional Comprehensive Economic Partnership (RCEP) that are, Thailand, Vietnam, Indonesia, Malaysia, Philippines, Singapore, Myanmar, Cambodia, Laos, Brunei, Australia, China, India, Japan, South Korea and lastly New Zealand. Data used are taken from The World Bank and OECD Data for the period of 2000 to 2018.

\section{The Non-Linear Factor Analysis}

This study uses nonlinear time varying factor model by Phillips and Sul (2007) as it has few advantages in order to study the transitional behavior of TPP and RCEP's countries total trade. Additionally, results from convergence give empirical estimation regarding the speed of convergence. This is to say, it captures how fast or how slow for one to converge to steady-state equilibrium. Furthermore, this method also provides a basis for a clustering algorithm. As a result, it allows formation of convergence clubs and observes transition behavior between clusters too. Apart from that, Phillips and Sul convergence test is a nonlinear model, which contains time varying components. Therefore, this nonlinear model is very crucial as it investigates the possible growth convergence or divergence over time and studies the heterogeneous transition paths across economies. In other words, this method identifies the convergence clubs behavior among time varying idiosyncratic transition coefficients that permits one to locate the sources of divergence in a panel. Hence, this method is useful in order to observe and measure transition toward a long run growth path as well 
as individual transitions over time period in relation with common trends, representative or aggregate variable. Therefore, in order to investigate the convergence of TPP and RCEP's countries in respect to their total trade, Phillips and Sul convergence method is adopted.

As Model Factor analysis provides the series decomposing into common and country-specific factors in a particularly frugal manner, it is an essential mechanism for investigating data sets with considerable time series and cross-section measurements. Panel data are usually decomposed by:

$X_{i t}=g_{i t}+a_{i t}$

In equation (1), $X_{i t}$ defined as Gross Domestic Product (GDP) for nation I and at time t, where $\mathrm{i}=1$.... and $\mathrm{t}=1 \ldots \mathrm{T}$. It is common that $X_{i t}$ can be decomposed as systematic, $g_{i t}$ and transitory, $a_{i t}$ into two components. In equation (1), $g_{i t}$ and $a_{i t}$ may contain both common and idiosyncratic factors

$X_{i t}=\left[\frac{g_{i t}+a_{i t}}{\mu_{t}}\right] \mu_{t}=\delta_{i t} \mu_{t}$ for all country, $\mathrm{i}$ and time, $\mathrm{t}$

By using the equation (2), the common and idiosyncratic factors in the panel can be separated by Phillips and Sul via factorizing the common stochastic trend component. It specifies the two time varying components; common, $\mu_{t}$ and idiosyncratic $\delta_{i t}$ is created by decomposing $X_{i t}$. Between $X_{i t}$ and the common component, $\mu_{t}$, the factor $\delta_{i t}$ represents a measurement of distance by which the error term and the unit specific component is dissolves and hence serves as the idiosyncratic component, which is changing over time. $\mu_{i t}$ represents as common trend component in panel and considered to possess various deterministic or stochastic trend attitude that influences the transitory element $a_{\text {it }}$ as $t \rightarrow \infty$.

The non-stationary transitional nature of factor loadings is suggested in semi parametric form for specifying the null hypothesis of convergence wherein every coefficient converges to some factor of certain constant;

$\delta_{i t}=\delta_{i}+\frac{\sigma_{i} \xi_{i t}}{L(t) t^{\alpha}}$

Where $\delta_{i}$ is fixed, across $\mathrm{i}, \xi_{i t}$ is iid $(1,0)$, idiosyncratic scale parameters is denoted by $\sigma_{i}$, slowly varying function is represented by $L(t)$, and $L(t)=\log t$, that is why $L(t) \rightarrow \infty$ as $t \rightarrow \infty$.

The rate at which the cross-sectional differences decaying to 0 is denoted by the parameter $\alpha$. For all $\alpha \geq 0$. $\delta_{\text {it }}$ converges to $\delta$ which is ensured from the formulation above.

\section{The Transition Path}

Since the time varying factor loadings $\delta_{i t}$, estimation provides fact about transition behavior of specific panel units so that it is a necessary concern of the strategy recommended by Phillips and Sul (2007). By applying its corresponding form, a smooth and effective method to obtain fact $\delta$ it is as regard:

$h_{i t}=\frac{X_{i t}}{\frac{1}{N} \sum_{i=1}^{N} X_{i t}}=\frac{\delta_{i t}}{\frac{1}{N} \sum_{i=1}^{N} \delta_{i t}}$

The loading coefficient $\delta_{i t}$ is measured from equation (4), which is associated with the panel average. For the economy i, alike $\delta_{i t}$, $h_{\text {it }}$ even traces out transition path though presently produces one is in association to panel average. Over time, corresponding to the average, a particular path for every $i$ is traced by variable $h_{\text {it }}$ for this reason it is denominated as path of transition. Together, form the common steady state growth path $\mu_{t}$ of country i's relevant deviation is as well measured by $h_{\text {it. }}$.

Therefore, path of transition $h_{\text {it }}$ reflect divergences from $\mu_{t}$ by forming, the average crosssectional of the corresponding path of transition of economy $i$ equalize unity. Moreover, the 
corresponding transition path, $\mathrm{h}_{\text {it }}$ converges to unity and the cross-sectional variation $\left(H_{t}\right)$ of the corresponding transition path converges to zero, if panels units converge and all the factor loading $\delta_{\text {it }}$ approximate to a fixed $\delta$. Which is as follows:

$H_{t}=\frac{1}{N} \sum_{i=1}^{N}\left(h_{i t}-1\right)^{2} \rightarrow 0$ and $\rightarrow \infty$

When testing convergence approaches, it suggests that the application is according with the long run behavior in the macroeconomic phenomena. Thus, it is usually desirable to eliminate business cycle factor using the smoothing technique to obtain $h_{i t}$ from $X_{i t}$. Accordingly, by incorporating a business cycle influence kit equation (4) can be written as:

$X_{i t}=\delta_{i t} \mu_{t}+k_{i t}$

Due to the adaptability and the point that Hodrick and Prescott (1997) smoothing filter quest simply the addition of smoothing series and not looking for preceding particularization of the characteristics of the common trend $\mu_{t}$ in $X_{i t}$, in this analysis, Hodrick and Prescott (1997) smoothing filter is adopted. Having computed the HP estimate:

Expanding the above cross sectional averages to assessed transition, is computed as:

$\widehat{h_{l t}}=\frac{\widehat{X_{l t}}}{\frac{1}{N} \sum_{i=0}^{N} \widehat{X_{l t}}}$

Where ${ }^{\wedge} \widehat{X_{l t}}$ are the filtered GDP series. Within the expectation, in small samples, the panel average $N^{-1} \sum_{i=1}^{N} \widehat{X_{l t}}$ is positive also asymptotical that is performed for many related economic time series for instance prices, income per capita or different gross.

\section{The Log-t Test}

By taking into consideration the varying factor statement from equation (2) and depending on the log t convergence test that depends on a simplistic time series regression, Phillips and Sul (2007; 2009) proposed a unique convergence test and clustering algorithm. The null and alternative hypothesis can presently be established.

Null hypothesis $H_{0}: \delta_{i}=\delta$, where for all $\mathrm{i}, \alpha \geq 0$, which indicates convergence for all nations. Alternative hypothesis, $H_{a}: \delta \neq \delta$ here, for some i and/or $\alpha<0$ indicating that no convergence for some nation. After estimating transition path, the variation ration or cross section $H_{1} / H_{t}$ is to be computed by acknowledging $\mathrm{H}_{\mathrm{t}}$ as:

$$
H_{t}=\frac{1}{N} \sum_{i=1}^{N}\left(\widehat{h_{l 1}}-1\right)^{2}
$$

The transition distance $H_{\text {_t }}$ has a limiting form, which is showed by Phillips and Sul (2007):

$H_{t} \sim \frac{A}{L(t)^{2} t^{2 \alpha}}$ as $\mathrm{t} \rightarrow \infty$

Where, positive constant is denoted by A, slowly varying function is explained by $L(t)=$ $\log (t+1)$, and the speed of convergence is $\alpha$. Usually, after removing a fraction $(r)$ of the sample, equation (9) is run. Phillips and Sul suggest at the some point, t become ( $r T)$, where $(r T)$ represents the integer part of $(r T)$, and $r=0.3$. For examining the convergence null hypothesis discussed above, log t test is carried out as regards:

$\log \left(\frac{H_{1}}{H_{t}}\right)-2 \log L(t)=\hat{c}+\hat{b} \log t+\widehat{\mu_{t}}$

Here, variation of cross-section is $\mathrm{Ht}$, at the beginning of the sample, variation ratio of crosssection is explained by $\mathrm{H} 1 / \mathrm{Ht}$, over the corresponding difference for each stage of period t, $\mathrm{H} 1$ (i.e. 
$\mathrm{Ht}$ at $\mathrm{t}=1)$, which means, $\mathrm{Ht}(\mathrm{t}, \ldots, \mathrm{T})$, from the common limit the distance of the panel is measured by $\mathrm{Ht} / \mathrm{H} 1$. At the same time, $\mathrm{L}(\mathrm{t})=\log (\mathrm{t})$ and $r>0$. The regression presented in equation (10) is regarded as log $t$ regression due to the log $t$ regressor. By applying the traditional t-statistic, if, $t b<-$ 1.65, we reject the $\mathrm{HO}$ of convergence. It can be concluded panel convergence, when the t-statistic,

tb recommends that $\hat{b}$ is else positive otherwise equals to zero. On the other hand, HO of convergence is rejected when $t_{b}$ recommends that $b$ is negative and significant.

By applying the traditional $t$-statisti ${ }_{c} s$, if $t_{b}<-1.65$, we reject the $H_{0}$ of convergence. It can be concluded panel convergence, when the t-statistics $t_{b}$ recommends that $b^{\wedge}$ is else positive otherwise equals to 0 . On another side, we reject the $H_{0}$ of convergence, when t-statistic, $t_{b}$ recommends that $b^{\wedge}$ is negative and significant.

\section{Empirical Result and Discussion}

Full Panel Convergence

The Log t-test method is used to measure the overall convergence test on aggregate level for TPP and RCEP countries by total trade. Table 1 and Table 2 represent the outcomes for full panel convergence (i.e., convergence among all countries) filtered with the Hodrick-Prescott filter (HAC) for TPP and RCEP respectively. In Table 1, it shows the full panel convergence in TPP for period sampling of year 2000 till 2016 rejecting the null hypothesis of total trade convergence with a t-statistics of 73.69 , hence denoting that the total trade is diverging. On the other hand, a full panel convergence for RCEP does not reject the null hypothesis of total trade convergence, as it has a t-statistics of 0.61 that denotes the total trade is converging. A full panel divergence or convergence could mean more than just an overall unity or even disunity, therefore, a further analysis of these sub-groups are needed.

Table 1. Results of full panel convergence (Log-t Test) in TPP countries

\begin{tabular}{|c|c|c|}
\hline Country & $\widehat{\boldsymbol{b}}$ & Remarks \\
\hline TPP member countries & $-73.68^{*}$ & Divergence \\
\hline
\end{tabular}

Note: Asterisk (*) denotes statistically significant at 5\% level. A 5\% significant value is -1.65 .

Table 2. Results of full panel convergence (Log-t Test) in RCEP countries

\begin{tabular}{|c|c|c|}
\hline Country & $\widehat{\boldsymbol{b}}$ & Remarks \\
\hline RCEP member countries & 0.61 & Convergence \\
\hline
\end{tabular}

Note: Asterisk $\left({ }^{*}\right)$ denotes statistically significant at 5\% level. A 5\% significant value is -1.65 .

In a full panel convergence, TPP is said to be diverging among its participating countries. This result can be supported with Petri, Plummer and Zhai (2014) work, mainly suggests the divergences is due to different interest among participating member economies; Venables (1999) mentioned that most regional agreements involving developing countries are usually resulted with divergence in their economic performance. Nevertheless, a divergent does not mean that there are no signs of convergence in the sub-group of its member countries. There are still groups of countries that possessed similar traits and at a level of equivalency, hence can be identified as club convergence. 
Besides that, surprisingly RCEP's t-statistics shows that the overall countries are converging, but comparatively based on its figure value it reflects a weak convergence among member countries. This is quite interesting as most of the convergence works on RCEP have found to be diverging (Venables (1999); Petri \& Abdul-Raheem (2014); Yi (2014); Zhang (2014)).

Despite that, the overall convergence of RCEP countries especially in terms of total trade could come into being due to some possible reasons. Firstly, the trend from transition path shows that there are quite a number of countries that are intersecting with each other, plus many countries are observed to be intertwined and are close together (i.e. united), as to compare with TPP. Secondly, a majority of RCEP countries belong in the Newly Industrialized Countries (NIC) to developing economic phase, thus it can be generally assume that they have similar range of volume of total trade among them. Lastly, most of the participating members are also under ASEAN, therefore there is a high chance that most countries are associated with the same established trade policy.

Transition Path

According to the Figure 1 and Figure 2 illustrates the relative transition path of each country's total trade. Transition path, $h_{i t}$ shows the growth progression for each country, relative to the sample average. This means, if $h_{i t}$ is above one, the relevant country's total trade is above cross sectional average and vice versa. It is assume that, in full panel countries that are converging, the relative transition path will show tendency of these countries to unite. Additionally, each slope on each curve represents the growth of total trade for the respective country, relative to the cross sectional average. Referring to Figure 4, TPP's full panel appears to be diverging among countries, hence we do not see clear signs of transition paths to unite. On the contrary, in Figure 5, RCEP's full panel appears to show countries that seemed to unite together with only a little convergence among countries especially around year 2014 to 2016.

Figure 1. Transition path of total trade in TPP

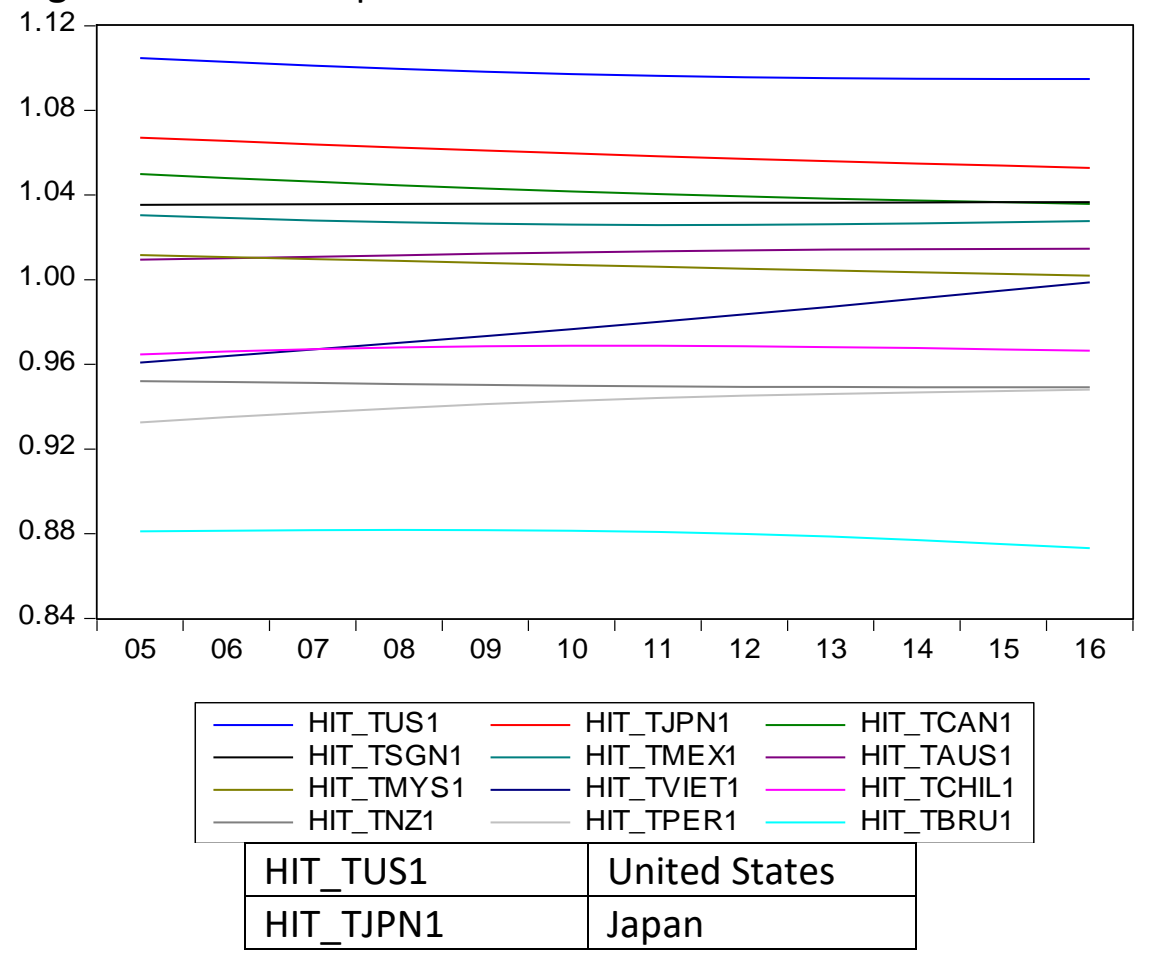


INTERNATIONAL JOURNAL OF ACADEMIC RESEARCH IN BUSINESS AND SOCIAL SCIENCES

Vol. 11, No. 14, Contemporary Business and Humanities Landscape Towards Sustainability. 2021, E-ISSN: 2222-6990 @ 2021 HRMARS

\begin{tabular}{|l|l|}
\hline HIT_TCAN1 & Canada \\
\hline HIT_TSGN1 & Singapore \\
\hline HIT_TMEX1 & Mexico \\
\hline HIT_TAUS1 & Australia \\
\hline HIT_TMYS1 & Malaysia \\
\hline HIT_TVIET1 & Vietnam \\
\hline HIT_TCHIL1 & Chile \\
\hline HIT_TNZ1 & New Zealand \\
\hline HIT_TPER1 & Peru \\
\hline HIT_TBRU1 & Brunei \\
\hline
\end{tabular}

Figure 2. Transition path of total trade in RCEP

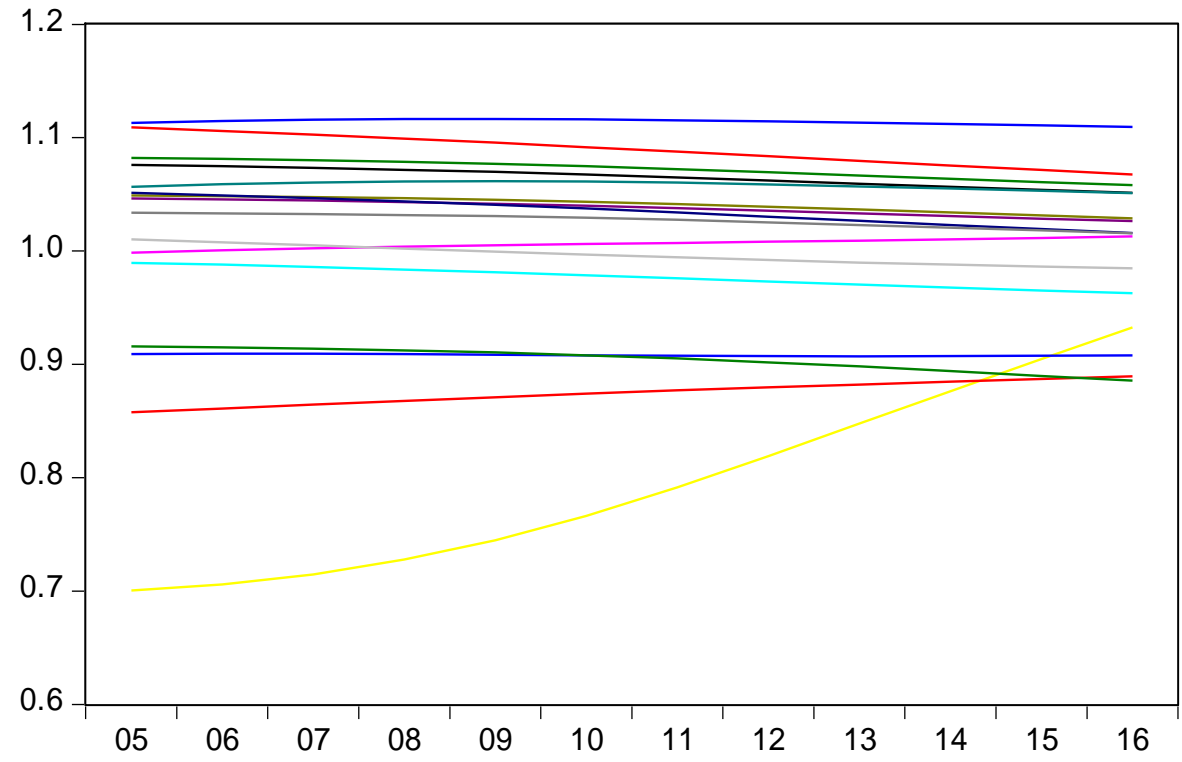

\begin{tabular}{|c|c|c|}
\hline $\begin{array}{ll} & \text { HIT_RCHI1 } \\
& \text { HIT_RSGN1 } \\
& \text { HIT_RAUS1 } \\
& \text { HIT_RINDO1 } 1 \\
& \text { HIT_RMYAN1 } \\
& \text { HIT_RBRU1 }\end{array}$ & $\begin{array}{l}\text { HIT_RJPN1 } \\
\text { HIT_RIND1 } \\
\text { HIT_RMYS1 } \\
\text { HIT_RPHIL1 } \\
\text { HIT_RCAM1 }\end{array}$ & $\begin{array}{r}\text { HIT_RK } \\
\text { HIT_RT } \\
\text { HIT_RV } \\
\text { HIT_RN } \\
\text { HIT_RL }\end{array}$ \\
\hline HIT_RCHI1 & China & \\
\hline HIT_RJPN1 & Japan & \\
\hline HIT_RKOR1 & Korea & \\
\hline HIT_RSGN1 & Singapore & \\
\hline HIT_RIND1 & India & \\
\hline HIT_RTHA1 & Thailand & \\
\hline HIT_RAUS1 & Australia & \\
\hline HIT_RMYS1 & Malaysia & \\
\hline HIT_RVIET1 & Vietnam & \\
\hline HIT_RINDO1 & Indonesia & \\
\hline
\end{tabular}




\begin{tabular}{|l|l|}
\hline HIT_RPHIL1 & Philippines \\
\hline HIT_RNZ1 & New Zealand \\
\hline HIT_RMYAN1 & Myanmar \\
\hline HIT_RCAM1 & Cambodia \\
\hline HIT_RLAO1 & Lao \\
\hline HIT_RBRU1 & Brunei \\
\hline
\end{tabular}

\section{Club Convergence}

The next move is to proceed with clustering countries in order to find respective core countries, number of clubs formed and tracking diverging countries based on total trade in TPP and RCEP member countries. This study assumes that, any particular member country in the group is able to converge at a different equilibrium state or diverge itself from the rest of the countries plus, the relative transition paths of each club will converge to a different constants. Therefore, log $t$ regressions also the HAC filter have been used and all its t-statistics results have been tabulated in Table 3 and Table 4.

Referring to Table 3 and Table 4, the test of convergence on total trade has resulted in four club convergence and four diverging countries for TPP, while RCEP have four club convergence and five diverging countries. 
Table 3. Results of Club Convergence of Total Trade in TPP

\begin{tabular}{|c|c|c|c|c|c|c|c|c|c|c|}
\hline 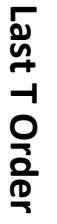 & $\begin{array}{l}2 \\
\frac{1}{5} \\
\stackrel{1}{z}\end{array}$ & $-\frac{n}{\frac{D}{D}} v$ & v & $\begin{array}{l}\underset{+}{\mathbb{D}} \\
\frac{0}{0} \\
\mapsto\end{array}$ & $\begin{array}{l}\stackrel{n}{\mathbb{D}} \\
\mathbb{D} \\
N\end{array}$ & $\frac{n}{\frac{D}{D}}$ & v $\frac{n}{\frac{n}{0}}$ & $\mapsto \frac{n}{\frac{D}{0}}$ & $\frac{2}{5}$ & 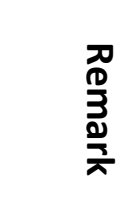 \\
\hline 1 & $\begin{array}{l}\text { United } \\
\text { States }\end{array}$ & $\begin{array}{l}\text { Bas } \\
\text { e }\end{array}$ & & & & & & & & $\begin{array}{l}\text { Diverg } \\
\text { ence }\end{array}$ \\
\hline 2 & $\begin{array}{l}\text { Japan } \\
27.65^{*}\end{array}$ & & $\begin{array}{l}\text { Bas } \\
\text { e }\end{array}$ & & & & & & & $\begin{array}{c}\text { Diverg } \\
\mathrm{e}\end{array}$ \\
\hline 3 & $\begin{array}{l}\text { Canad } \\
\text { a }\end{array}$ & $11.87^{*}$ & - & $\begin{array}{l}\text { Bas } \\
\text { e }\end{array}$ & & & & & 1 & $\begin{array}{c}\text { Conve } \\
\text { rge }\end{array}$ \\
\hline 4 & $\begin{array}{l}\text { Singap } \\
\text { ore }\end{array}$ & & & $\begin{array}{l}3.7 \\
4\end{array}$ & & & & & 1 & $\begin{array}{c}\text { Conve } \\
\text { rge }\end{array}$ \\
\hline 5 & Mexico & & & $\begin{array}{l}2.1 \\
6\end{array}$ & Base & & & & 2 & $\begin{array}{c}\text { Conve } \\
\text { rge }\end{array}$ \\
\hline 6 & $\begin{array}{l}\text { Austral } \\
\text { ia }\end{array}$ & & & & 1.04 & & & & 2 & $\begin{array}{c}\text { Conve } \\
\text { rge }\end{array}$ \\
\hline 7 & $\begin{array}{l}\text { Malays } \\
\text { ia }\end{array}$ & & & $5.18^{*}$ & - & $\begin{array}{l}\mathrm{Ba} \\
\text { se }\end{array}$ & & & 3 & $\begin{array}{c}\text { Conve } \\
\text { rge }\end{array}$ \\
\hline 8 & $\begin{array}{l}\text { Vietna } \\
\text { m }\end{array}$ & & & & & $\begin{array}{l}3.1 \\
5\end{array}$ & & & 3 & $\begin{array}{c}\text { Conve } \\
\text { rge }\end{array}$ \\
\hline 9 & Chile & & & & & $\begin{array}{l}0.1 \\
4\end{array}$ & $\begin{array}{l}\text { Bas } \\
\text { e }\end{array}$ & & & $\begin{array}{c}\text { Diverg } \\
\mathrm{e}\end{array}$ \\
\hline $\begin{array}{l}1 \\
0\end{array}$ & $\begin{array}{l}\text { New } \\
\text { Zealan } \\
\text { d }\end{array}$ & & & & & $5.82^{*}$ & ${ }^{-}$ & Base & 4 & $\begin{array}{c}\text { Conve } \\
\text { rge }\end{array}$ \\
\hline $\begin{array}{l}1 \\
1\end{array}$ & Peru & & & & & & & 6.81 & 4 & $\begin{array}{c}\text { Conve } \\
\text { rge }\end{array}$ \\
\hline $\begin{array}{l}1 \\
2\end{array}$ & Brunei & & & & & & & $\begin{array}{l}- \\
23.04 \\
*\end{array}$ & & $\begin{array}{c}\text { Diverg } \\
\mathrm{e}\end{array}$ \\
\hline
\end{tabular}

Note: Asterisk $\left({ }^{*}\right)$ denotes statistically significant at 5\% level. A 5\% significant value is -1.65 .

TPP has a total of four club convergence and four divergence countries. From Figure 6 , we can see that United States and Japan is a divergent. This is probably due to their massive volume of total trade and not to mention both countries are renowned as industrialized nations of the world, meaning their development in trade are comparatively more advanced than the rest. Interestingly, the TPP are likely to accommodate economies that have yet made any FTA with United States essentially Japan and Vietnam (Petri, Plummer \& Zhai, 2014), thus as for this case we can see that the relationship between United States and Japan has been amplified. 
Furthermore, in terms of convergence in clubs, Canada and Singapore has formed the first club, this could be supported by the fact that East and South Asia countries have long established firm relationships with North America (i.e. Canada) especially in terms of their investment as well as trade intensities (Petri, 1994) moreover their trade path pattern are alike, though initially Canada was leading, Singapore has managed to catch up with Canada later on. The next club would be of Mexico and Australia. Mexico's famous relationship with United States notably in NAFTA had made it more desirable and important in the trading world. Besides TPP, Mexico have engaged with many other FTAs that have encouraged competitiveness and widened its trade openness hence the high trade volume. Nevertheless, Australia and Mexico trade relationship has been strong and secured even before TPP, therefore it is natural that both are mutually benefited and are at par with each other in addition with the enhancement of TPP. Following that is the third club, consisting of Malaysia and Vietnam. As for the case of Vietnam, it is very impressive that they have successfully escaped from being one of the poorest nations and shifted to become a lower middle income country. Considering that their economic performances is getting sturdier especially in terms of exporting manufacturing products, recovering its agriculture sector, high domestic demand together with rising foreign investment inflows, there is no surprise in terms of total trade, Vietnam has managed to be at par with Malaysia, a NIC. In addition, Chile and Brunei appears to be diverging from others. Their trade development path does not show tendencies of converging or caching up. However, Chile and Brunei has something in common, both rely highly on their natural resources as their primary export products. A slight decrease of global demand and prices would tremendously affect their total trade volume and trade development growth. Chile main exports are copper, but in year 2011 till 2017, copper price have been declining, consequently it has slowed down their volume of exports and private investment as well as growth. Whereas for Brunei, relatively it does not have a big volume of trade and is not as active in trading as the others, hence we can see Brunei's trade development path are quite flat and not converging. Therefore, it is quite impossible for it to be at par with other countries, hence the divergence. Last but not least, the fourth club, New Zealand and Peru. Though initially there is a gap between these two countries, but over the years Peru has managed to catch up with New Zealand and be at the same level in terms of trade development.

Other than that, besides only looking into the number of club convergence we can also analyze their transition path in determining the strength of convergence. TPP's development trade path does not show that much unity and somewhat scattered. There is clearly a big gap especially between United States and Brunei plus no signs of possible catching up with the rest of the members. Thus, this signifies that TPP's economies have a rather weak convergence among member countries, plus it also reflects the differences and discrepancy in their trade development progress as a whole.

Despite all the clustering of countries, organizations and agreements like the ASEAN Consultative Committee on Standard and Quality also the 1998 ASEAN Framework Agreements in Mutual Recognition Arrangements, have made it their objective to find convergence of standards and attain region wide regulatory target, particularly between ASEAN and TPP members. Therefore, as one entity TPP member countries need to work harder and narrow down their dissimilarities. 
Table 4. Results of Club Convergence of Total Trade in RCEP

\begin{tabular}{|c|c|c|c|c|c|c|c|c|c|c|c|c|}
\hline 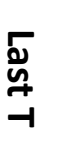 & $\begin{array}{l}\text { } \\
\stackrel{5}{5} \\
\stackrel{+}{2}\end{array}$ & $\mapsto \underset{\frac{D}{0}}{\stackrel{n}{0}}$ & $\sim \frac{n}{\frac{D}{0}}$ & 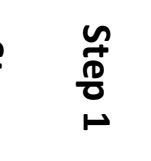 & 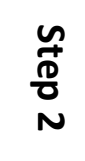 & $\mapsto \underset{\frac{D}{0}}{\stackrel{n}{0}}$ & $N \frac{n}{\frac{n}{0}}$ & $\mapsto \frac{n}{\frac{D}{0}}$ & $\sim \underset{\frac{n}{0}}{\frac{n}{0}}$ & $\mapsto \frac{n}{\frac{n}{0}}$ & $\frac{}{\frac{5}{\sigma}}$ & 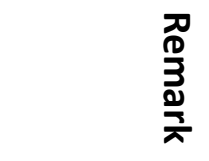 \\
\hline 1 & China & Base & & & & & & & & & & Divergence \\
\hline 2 & $\begin{array}{l}\text { Japan } \\
9.26 *\end{array}$ & - & Base & & & & & & & & 1 & $\begin{array}{c}\text { Convergen } \\
\text { ce }\end{array}$ \\
\hline 3 & Korea & & 6.52 & & & & & & & & 1 & $\begin{array}{c}\text { Convergen } \\
\text { ce }\end{array}$ \\
\hline 4 & $\begin{array}{l}\text { Singapo } \\
\text { re }\end{array}$ & & 4.57 & $\begin{array}{l}\text { Bas } \\
\text { e }\end{array}$ & & & & & & & 2 & $\begin{array}{c}\text { Convergen } \\
\text { ce }\end{array}$ \\
\hline 5 & India & & & $\begin{array}{l}4.1 \\
1\end{array}$ & & & & & & & 2 & $\begin{array}{c}\text { Convergen } \\
\text { ce }\end{array}$ \\
\hline 6 & Thailand & & & $-61.62^{*}$ & $\begin{array}{l}\text { Bas } \\
\text { e }\end{array}$ & & & & & & & Divergence \\
\hline 7 & $\begin{array}{l}\text { Australi } \\
\text { a }\end{array}$ & & & $3.07^{*}$ & & Base & & & & & & Divergence \\
\hline 8 & $\begin{array}{l}\text { Malaysi } \\
\text { a }\end{array}$ & & & & & $-7.45^{*}$ & Base & & & & 3 & $\begin{array}{c}\text { Convergen } \\
\text { ce }\end{array}$ \\
\hline 9 & Vietnam & & & & & & 3.15 & & & & 3 & $\begin{array}{c}\text { Convergen } \\
\text { ce }\end{array}$ \\
\hline 10 & $\begin{array}{l}\text { Indonesi } \\
\text { a }\end{array}$ & & & & & & 3.10 & Base & & & & Divergence \\
\hline 11 & $\begin{array}{l}\text { Philippin } \\
\text { e }\end{array}$ & & & & & & & $2.24 *$ & Base & & & Divergence \\
\hline 12 & $\begin{array}{l}\text { New } \\
\text { Zealand }\end{array}$ & & & & & & & & $-7.13^{*}$ & Base & 4 & $\begin{array}{c}\text { Convergen } \\
\text { ce }\end{array}$ \\
\hline 13 & $\begin{array}{l}\text { Myanm } \\
\text { ar }\end{array}$ & & & & & & & & & 2.87 & 4 & $\begin{array}{c}\text { Convergen } \\
\text { ce }\end{array}$ \\
\hline 14 & $\begin{array}{l}\text { Cambod } \\
\text { ia }\end{array}$ & & & & & & & & & 3.40 & 4 & $\begin{array}{c}\text { Convergen } \\
\text { ce }\end{array}$ \\
\hline 15 & Lao & & & & & & & & & 3.78 & 4 & $\begin{array}{c}\text { Convergen } \\
\text { ce }\end{array}$ \\
\hline 16 & Brunei & & & & & & & & & 4.08 & 4 & $\begin{array}{c}\text { Convergen } \\
\text { ce }\end{array}$ \\
\hline
\end{tabular}

Note: Asterisk $\left(^{*}\right)$ denotes statistically significant at 5\% level. A 5\% significant value is -1.65 .

RCEP has a total of four clubs convergence and five diverging countries. Having 16 countries with different interest, economic backgrounds and developmental stages in pursuit of finding common grounds is definitely a challenge. 
One of the countries that made this agreement much more attractive is China. With its huge volume of total trade and global influences in the trade market, RCEP is foresee to help China and the associate countries prosper even more. However, due to its faster and somewhat different level of trade development and advancement, China is seen to be diverging from the rest. Moving on, the first club would be of Japan and Korea. In comparing Japan with Korea, Japan has higher volume of trade and is more advanced in industrializing, but throughout the years, their development in trade has slowed down and converges with Korea later on. Still, both are Asian's large industrial economies that basically dominated the world trade and FDI. On top of that, according to the Observatory of Economic Complexity (OEC), in 2016 Japan was $4^{\text {th }}$ while Korea $7^{\text {th }}$ largest export economy worldwide. The second club is, Singapore and India. India is a NIC, with the advantage of its large populations, they have channelled this to an opportunity to focus more on trading in manufacturing and agricultural sectors hence have made significance economic improvement over the years. Furthermore India has also managed to make trading alliances with major traders such as Singapore, United States, China and also United Arab Emirates. Surprisingly, this has proven to work and now India has similar trade development trend with Singapore, a well-known developed country.

Furthermore, Thailand and Australia showed divergence. What is interesting is, even before RCEP, Thailand and Australia were already big partners in trade. In fact, since 2005, they have participated in a pact called Thailand-Australia Free Trade Agreement (TAFTA), since then their volume of trade grew even bigger. Although both economies grew together, Thailand's (NIC) trade volume was not as big as Australia's (developed country), thus this could probably be one of the reasons on why they diverge. Other than that, there are also Indonesia and Philippines that is diverging. Their dominant trading partners are mostly in the RCEP, such as Singapore, Korea, Japan, China, and United States also both are rather active in the trade market. Regardless of being a NIC or a developing country respectively, when compared with other big economies with higher trade development, it tends to diverse. Due to this, they do not show similar trend path or signs of unity.

Turning to the third club, Malaysia and Vietnam. Recalling from TPP, Malaysia and Vietnam are also in one group, so it certainly shows resemblances in terms of trade. Malaysia and Vietnam are known to be in the middle income groups and comparatively have small economies. According to Petri (1990), he mentioned that there are higher tendency for more active trade and investment for countries that are relatively small, open economies and in a medium income category. Lastly, the core club that comprises the most number of countries, which are New Zealand, Myanmar, Cambodia, Lao and Brunei. Despite having a comparatively low volume of total trade than others and at the same time does not have same trade development pattern but, towards the end they show signs of catching up and unity. New Zealand, Myanmar, Cambodia and Lao have similarities in economies, as all are involved highly in the agricultural sector. Over the years, it has started to industrialized itself in order to compete globally. Additionally, as stated by Grimsditch (2017), China has also been vigorously engaging in Myanmar, Cambodia and Lao agricultural sector as a trading partner, investor and also a predominant donor. Consequently, this could help these less developed countries to boost their economies. Looking into Brunei's top ten trading partners, most are in fact in RCEP, with the addition of United States, United Kingdom and Germany. Brunei was placed $108^{\text {th }}$ largest export economy in 2016 and at the same time has the lowest trade volume among RCEP countries. Besides that, in this club four out of five belong in ASEAN namely, Myanmar, Cambodia, 
Lao and Brunei thus it is natural that they are implementing the same trading policy and have been actively trading with each other, hence the club convergence.

All in all, though RCEP does not show a strong convergence among participating countries, we can still expect ASEAN economies to be at an advantage and yield at least small benefits from the agreement (Petri, Plummer and Zhai, 2014).

Choosing TPP or RCEP?

When it comes to choosing the more 'converge' partnership, there are a few factors that need to be analyze, such as the number of club convergence, existence of core countries and trade development path of each partnership.

Firstly, the number of club convergence. It is usually by picking the one with the least number of clubs, as it shows the least dissimilarities, however as for this case, both TPP and RCEP got four convergence clubs, so it is still undecided. Secondly, the existence of core countries. In TPP, there are no core countries, as all have upmost two countries in a club, whereas in RCEP, club number four has five countries grouped into one club making it the core countries of RCEP. In a way, this made RCEP countries look more solid and united as it shows a stronger base that holds member countries together. Thirdly, the trade development path. When comparing both TPP and RCEP overall transition path, RCEP reflects more unity as almost all of its countries development trend shows the same trend pattern and are unified. Plus, RCEP countries have a quite number of trade development path that intersects each other, thus signifies convergence and higher chances for each countries to catch up with each other.

\section{Conclusion}

In this study, a convergence test method developed by Phillips and Sul (2007) has been applied on both TPP and RCEP countries for the period of 2000 till 2016. This method was specifically chosen because it is not rigid towards the stationary assumption and is not restricted to only convergence and divergence issues as it also covers the clustering-grouping algorithm (Dayang Affizah, 2011). As a result, this study is able to produce outcomes that are thorough and descriptive in regards of convergence issues in TPP and RCEP.

On the subject of TPP, its 11 signatories members are of United States (as of 2016), Japan, Canada, Singapore, Mexico, Australia, Malaysia, Vietnam, Chile, New Zealand, Peru and Brunei. From here, we can see that most of the countries are among the biggest and top economies of the world and only a few that's comparatively less developed.

Moving on to RCEP, with its 16 members China, Japan, Korea, Singapore, India, Thailand, Australia, Malaysia, Vietnam, Indonesia, Philippines, New Zealand, Myanmar, Cambodia, Lao and Brunei shows divergence. With a high mixture of economies from among the highly industrialized countries like Japan and Singapore to a much less developed like Myanmar and Lao, the disparity of trade intensity, individual pace and trade development aspects are huge. This is something they must address and take precaution of.

TPP and RCEP has become a hot topic for years, many studies have been done on finding their economic and political feasibilities. At the same time, there were also negotiations on opening new FTAs and RTAs with even more countries and even bigger ambitions, for instance FTAAP. Therefore, to keep up and still be relevant to the economic and political world, these partnerships need to work out their differences and find ways for all countries to benefit equally meanwhile pushing each other 
for trade advancement, consequently, this could lead to the increment of unity. Being in a strong united RTA would definitely expand the possibilities for a deeper and less complex integration policies within the region.

To summarize, the Trans-Pacific Partnership's overall convergence among member countries shows it is diverging, and clustered themselves into four convergence clubs. As for Regional Comprehensive Economic Partnership's overall convergence reflects it is converging though could be interpreted as a weak convergence, and clustered themselves into four convergence clubs. This study concludes that it is keen towards RCEP, as it shows more similarities and unity among participating member as to compare with TPP.

\section{References}

Apergis, N., Christou, C., \& Miller, S. (2012). Convergence patterns in financial development: Evidence from club convergence. Empirical Economics, 43(3). 1-29.

Baumol, W. J. (1986). Productivity growth, convergence, and welfare: What the long-run data show. American Economic Review, 76, 1072-1085.

Battisti, M., Vaio, G. D. \& Zeira, J. (2015). Convergence and Divergence in Growth Regressions. Retrieved from https://www.bde.es/f/webbde/INF/MenuHorizont al/SobreElBanco/Conferencias/2015/Archivos/29_1510A_ZEIRA_PAPER.pdf

Battisti, M., Vaio, G. D., \& Zeira, J. (2016). A New Way to Measure Divergence of Output Across Countries. Retrieved from https://www8.gsb.columbia.edu/facultyresearch/sites/facultyresearch/files/finance/Macro \%20Workshop/BDZ\%20March\%202016_0.pdf

Ben-David, D. (1996). Trade and convergence among countries. Journal of International Economics, 40(3-4), 279-298.

Borsi, M. T., \& Metiu, N. (2013). The evolution of economic convergence in the European Union. Discussion paper, Deutsche Bundesbank.

Basu Das, S., \& Jagtiani, R. B. (2014). The Regional Comprehensive Economic Partnership: New paradign or old wine in a bottle? Economics working paper, Institute of Southeast Asian Studies.

Dent, C. M. (2010). Free trade agreements in the Asia-Pacific a decade on: Evaluating the past, looking to the future. International Relations of the Asia-Pacific, 10(2), 201-245.

Affizah, D. A. M., Mahbubur, M. R., Afiza, N. A. B., \& Ting, M. S. (2017). A convergence clubs of Regional Comprehensive Economic Partnership (RCEP) countries: A wise choice? Jurnal Ekonomi Malaysia, 51(2). 119-132.

Hodrick, R. J., \& Prescott, E. C. (1997). Postwar US business cycles: An empirical investigation. Journal of Money, Credit, and Banking, 29(1), 1-16.

Md. Mahbubur, R., Affizah, D. A. M., Afiza, N. A. B., \& Affendy, M. A. (2017). Sectoral GDP convergence of selected RCEP countries: Lead or lags? International Journal of Business and Society, 18(2), 669-676.

Andronnikova, O. (2014). Psycho Educational Conditions of the Development of Safe and Remediation of Dangerous Behaviors of a Child. International Journal of Academic Research in Psychology, 1(1), 32-40. 
Petri, P. A., \& Abdul-Raheem, A. (2014). Can RCEP and the TPP be pathways to FTAAP? Pacific Economic Cooperation Council, Sate of The Region, 2014. Retrieved from https://ssrn.com/abstract=2513893

Petri, P. A., Plummer, M. G., \& Zhai, F. (2014). The TPP, China and the FTAAP: The case for convergence. Paper presented at Asia-Pacific Economic Integration, Honolulu: East-West Center.

Phillips, P. C. B., \& Sul. D. (2007a). Transition modelling and econometric convergence tests. Econometrica, 75(6), 1771-1855.

Phillips, P. C., \& Sul, D. (2009b). Economic transition and growth. Journal of Applied Econometrics, 24(7), 1153-118518(3). 439-460. 